\title{
Reflections of ELT Students on Their Progress in Language and Vocabulary Use in Portfolio Process
}

\author{
Selami Ok ${ }^{1}$ \\ ${ }^{1}$ Department of English Language Teaching, Pamukkale University, Denizli, Turkey \\ Correspondence: Selami Ok, Pamukkale University, Faculty of Education, Department of English Language \\ Teaching, Kınıkl1 20070, Denizli, Turkey. Tel: 90-258-296-1027. E-mail: selamiok@pau.edu.tr
}

Received: November 14, 2013 Accepted: December 22, 2013 Online Published: January 6, 2014

doi:10.5539/elt.v7n2p53 URL: http://dx.doi.org/10.5539/elt.v7n2p53

\begin{abstract}
Writing in the target language is an essential skill to be developed, and to this end, reading and writing skills need to be integrated so that students can be engaged in an active and effective learning process in order to help them create a positive change in their progress and achievement. Hence, it should be highly important to see in an integrated reading-writing course, particularly in an ELT context, to what extent students perceive the portfolio-keeping process with respect to language and vocabulary use. This study aimed to explore the reflections of freshmen learners at an ELT department in Turkey on the portfolio process in The Advanced Reading-Writing Course with respect to their progress in language and vocabulary use. Qualitative survey methodology was used to gather the data. The participants were 46 freshman learners attending The Department of English Language Teaching. The data were collected through the reflective essays in which the students reported their views on the portfolio process as well as their development. The data analysis was done by means of content analysis. Unstructured interview technique was also used to capture the students' perceptions and learning experiences. The findings indicate that the portfolio-keeping process as part of the Advanced Reading-Writing Course gave the students the opportunity to develop their level in writing with respect to language and vocabulary use. The students report that they benefited from the integration of reading and writing skills in spite of the workload, which also reflected into their speaking skill and pronunciation as well. The process also gave the students the opportunity to self-evaluate their progresses in both writing and speaking skill. It is also reported by the students that the portfolio-keeping process helped the students build their self-confidence in language and vocabulary use. Consequently, the findings show that portfolio-keeping enhances the gains throughout the process and helps to create a positive attitude towards writing in the target language.
\end{abstract}

Keywords: portfolio, language and vocabulary use, integrated language skills, ELT

\section{Introduction}

The concept of portfolio, which can be defined as systematic collection of students' products in order to exhibit their progress and achievement in a field of study, has been extensively used and applied in teaching a foreign language over the last couple of decades. Various research studies and the scholars who strongly believe in the use of a portfolio process in language classroom specifically focused on the benefits of and purposes behind a portfolio-keeping process (Herman, Gearhart, \& Aschbacher, 1996; Murphy \& Camp, 1996; Hamp-Lyons \& Condon, 2000; Weigle, 2000; Delett, Barnhardt, \& Kevorkian, 2001; Lo, 2010). It is generally agreed that a student portfolio is not a folder composed of a student's products, but rather a purposeful collection of written pieces, or 'selected entries compiled in accordance with class goals' (Johns, 1995, p. 1), which demonstrates what a student has experienced throughout the process of learning, his/her growth and achievement (Moya \& O’Malley, 1994; Arter, Spandel, \& Culham, 1995; Gottlieb, 1995; O’Malley \& Pierce, 1996; Johnson \& Rose, 1997; Mullin, 1998; Hamp-Lyons \& Condon, 2000; Brown, 2004). In short, student portfolio can be used as a tool to assess multiple dimensions of language learning by evaluating both the quality of their written products and their progress over time (O’Malley \& Pierce, 1996; Brown, 2004).

For instance, Herman et al. (1996, p. 29) offer a set of purposes for portfolio use and assessment which have to be considered before attempting to apply a portfolio-keeping process: 
accountability in evaluating program or curriculum effectiveness, evaluating individual student progress and certifying student accomplishment, diagnosing students' needs, ..., helping teachers become more effective, encouraging reflective practice at the school and classroom levels, supporting teachers' professional development, helping students become better learners, promoting student's self-assessment and motivating student performance. (Weigle, 2000, p. 212)

Of these purposes, diagnosing students' needs, helping students become better learners and motivating students' performance are merely three key features of portfolio-keeping process which can naturally work to the benefit of students, apart from instructors, by encouraging a sort of reflective interaction on the way to becoming effective and successful learners. In support of this, Delett et al. (2001, p. 559) point out that 'portfolios provide a portrait of what students know and what they can do, offer a multi-dimensional perspective of student progress over time, encourage student self-reflection and participation, and link instruction and assessment.' Similarly, Hamp-Lyons and Condon (2000) offer a set of features that can be commonly observed in a typical portfolio, some of which relate to the benefits of portfolio-keeping process, saying that:

It enables the writer to display a range of writing performances, in different genres and for different audiences and purposes, possesses context richness as it reflects the learning situation and demonstrates what the writer has accomplished within that context, and can provide a means for measuring growth along specific parameters, such as linguistic accuracy or the ability to organize and develop an argument. (Weigle, 2000, p. 199)

Apart from the other features, context richness and linguistic accuracy seem to be only two essential criteria for all instructors who have decided to evaluate students' products within the wholeness of a portfolio over a period of time.

As the fundamental aim of a portfolio process is to provide evidence of students' ability and development in writing, the most striking features of a portfolio process are collection of students' written products over a period of time, selection of those pieces representing a student's progress and reflections by students. As Johns (1995, p. 1) pointed out, "through reflections, students can develop metacognitive awareness of texts and situations and of their processes and strategies when approaching various texts or tasks." Johns also stressed that "students may also be encouraged to judge their own work in their reflections and to compare several of their attempts to perform literacy tasks." Hamp-Lyons and Condon (2000, p. 119) emphasize that 'without reflection all we have is simply a large folder.' Thus, what a portfolio will include has to be determined by students, and a reflective essay that aims to inform the instructor about the content of a portfolio and reasons for selecting specific pieces is essential while designing a portfolio. In this way, students can discuss to what extent each product represents and reflects their strengths, development and achievement in writing, which naturally means an active involvement of learners in decision-making and evaluation of their progress and achievement.

The "meaningfulness principle", apart from the "communication" and "task" principles as suggested by Richards and Rodgers (2001, p. 161) as the elements underlying communicative language teaching, means that language that is meaningful to the learner supports the learning process. From this perspective, learning activities and teaching materials can be selected according to how well they engage the learner in meaningful and authentic language use. By having students involve in a portfolio-keeping process, reading and writing activities and/or tasks can be done based on the principle of "meaningfulness" in an integrated model in order to get them to participate in the process with a high level of motivation and get pleasure out of intelligible language production. In this sense, a systematic collection of written products in an integrated reading-writing course can be preferred as an ideal procedure, not only to integrate the two language skills and enable students to transfer their gains from one skill into the other, but also to create a meaningful interaction between the learner and language act by engaging students actively in an interesting and motivating process, in which each student's development is to be observed over time, providing them with regular feedback and giving them the opportunity to revise their products throughout an academic term or year.

As a consequence of such a process in a language course, students can be helped 'to be aware of the pedagogical goals and content of the course..., selecting and creating their own goals and objectives from a range of alternatives' (Nunan \& Lamb, 1996, p. 12). On top of this awareness, Murphy and Camp (1996, p. 113) emphasize the fact that keeping a portfolio offers students the opportunity 'to learn to exercise judgment about their own work, monitor their own progress, set goals for themselves, and present themselves and their work to others.' Along with this, students can develop a sense of ownership of their personal development in writing in an academic context, and in the course of time, an instructor can readily take a more realistic picture of a student's progress in language use and vocabulary learning; in other words, in syntactic and morphological accuracy. 


\section{Method}

This present study aimed to identify and present the reflections of the freshmen students attending a department of ELT in Turkey on the implementation of portfolio process as part of The Advanced Reading and Writing Skills Course with respect to their development in language and vocabulary use based on the views given in the reflective essays and interviews.

A qualitative research design was used in this study. As Denzin and Lincoln $(1994$, p. 2) stated, a qualitative research design involves an "interpretive, naturalistic approach to its subject matter", and aims to study things in their natural setting and attempts to make sense of the data.

\subsection{Research Context and Participants}

The data in this study were gathered at The Department of English Language Teaching, Faculty of Education, Pamukkale University, Denizli, Turkey. The participants were 46 freshmen (32 female and 14 male) students and they had been exempted from the prep class based on the passing scores over 70 in the proficiency exam administered at the School of Foreign Languages.

Portfolio-keeping was a compulsory component of The Advanced Reading-Writing Skills Course in both Fall and Spring terms. The students also take Listening and Pronunciation, Oral Communication Skills and Contextual Grammar courses in our program. In the second term, they take Lexis course in addition to these skills courses. In our case, The Contextual Grammar and The Advanced Reading-Writing Courses were combined and taught by the researcher in order to have more class hours with the students and integrate the two courses more effectively.

\subsection{Data Collection Instruments}

The data used in this study were collected through two instruments. Firstly, the reflective essays written by the students as part of their portfolios were used as the written documents to identify the students' views on the process. Secondly, an unstructured interview was carried out towards the end of the spring term with a group of 10 randomly-selected students. Patton (2002, p. 4) says that qualitative findings can be collected by means of three ways of data collection: open-ended interviews, direct observations, and written documents (Tailor, 2005, p. 103).

\subsection{Data Collection Procedure}

The data collection procedure in this study covered two academic terms. The participant students were trained in a one-hour session in the first week of the academic year on the essential characteristics of a portfolio process, what a student's portfolio must contain, the assessment criteria to be used and requirements. They were also shown sample student portfolios from a previous year. The students were asked towards the end of the spring term to add their views in their reflective essays about the portfolio-keeping process regarding their progress in language and vocabulary use.

Ten students were randomly selected for an unstructured interview and informed that participation in the interview session would be voluntary and would not influence their scores. To "establish rapport" beyond any preconception (Fontana \& Frey, 1994), the students invited for the interview were told that it was important to give accurate information in order to ensure the validity and reliability of the findings and results, and that the results would be used only for research purposes.

Unstructured interview aims to discover certain aspects of research question; and therefore, there would be no expectation for a previously determined question or answer (Yıldırım \& Şimşek, 2008, p. 120); in other words, without imposing any prior categorization that may limit the field of inquiry (Fontana \& Frey, 1994, p. 365), the intention is to create a relaxed atmosphere in which respondents may reveal more than they would in formal contexts (Dörnyei, 2007, p. 135). In this study, the students participating in the interview session were asked to give their opinions in Turkish in a couple of minutes and they were recorded on the spot. These opinions were later translated into English by the researcher. In order to hide the real identities of the students, numbers or pseudonmys were used instead of their names where necessary.

\subsection{Data Analysis}

In a portfolio-keeping process, students are expected to collect their written products systematically, reflect on their work and decide how to arrange the portfolio, and then, they are asked to write a reflective essay about their development and tell how pieces in the portfolio represent their development (Hamp-Lyons \& Condon, 2000). In this study, the reflective essays were used as the written documents to capture the participants' reflections on various aspects of the portfolio process with respect to progress in language and vocabulary development. 
Content analysis technique was used in order to identify and classify the students' opinions. Content analysis can be used for isolating, counting, and interpreting the concepts, problems, and subjects repeated in collected data (Miles \& Huberman, 1994; Denzin \& Lincoln, 1998). Each reflective essay was read by the researcher and each specific opinion was underlined and given a code. A name that is closest to the concept it was describing was used whilst giving names to the codes (Miles \& Huberman, 1994; Strauss \& Corbin, 1990), such as "lang. use" to mean "language use" covering grammar use; "voc. use" to mean "vocabulary use". Then, another instructor was asked to read a second copy of the underlined opinions in order to make sure that they fall into the same thought group and to increase the validity and reliability of the findings. In this sense, Miles and Huberman (1994, p. 64) note that "definitions become sharper when two researchers code the same data set and discuss their initial difficulties", and stress that "check-coding not only aids definitional clarity, but also is a good reliability check." Furthermore, Trumbull (2005, p. 121) recommends using another coder for the validation of the process in order to avoid scoring any data subjectively, and stresses that a percentage agreement between $80-90 \%$ is essential in order to establish coder reliability.

The formula Reliability $=$ number of agreements/ (total number of agreements + disagreements) (Miles \& Huberman, 1994) was used, and the inter-coder reliability rate for this study was calculated as .88, which was quite high (55 agreements vs. 7 disagreements). The disagreements were rechecked by a second coder, and as a result, the opinions derived from the reflective essays were first categorized under two broad themes which were specifically focused on in this paper: (1) progress in language use, (2) progress in vocabulary use. While working on the students' opinions, it was seen that some of the opinions were also related to the benefits of integration of language skills, self-assessment of personal progress and building self-confidence in language and vocabulary use. These opinions were classified separately under different sub-headings.

\section{Findings and Interpretation}

The findings of the study are presented under five sub-headings as: (a) reflections on progress in language use, (b) reflections on progress in vocabulary use, (c) reflections on the benefits of integration of language skills, (d) reflections on self-assessment of personal progress and (e) reflections on building self-confidence in language and vocabulary use.

\subsection{Reflections on Progress in Language Use}

Some students who took part in the study gave opinions on their progress in language use covering grammar use. The opinions were grouped according to the thought group in which they fall.

Opinions \#1, \#2 and \#3 indicate a comparison of what the students can do at the beginning and at the end of the course, and it seems that the length and complexity of sentences can be seen as a good indicator for the success of a portfolio-keeping process.

[1] "Because of the preparations for the university exam last year, I didn't do anything to improve my writing skill in English. At the beginning of the course, I used to make short sentences, but in time, as I read texts on various topics in our course books during the year, I was able to make longer sentences.

[2] "I started to make more complex and longer sentences in my essays."

[3] "When I compare the first homework with the others, I can see that there is a lot of development in my language usage. It is not enough to know only grammar rules. It is necessary to use them in proper places. Although I haven't much problem about grammar, I can add new things on what I learned previously. It is becoming easier for me to make complex sentences."

Opinions \#4 and \#5 tell us that integrating the Contextual Grammar Course with The Advanced Reading-Writing Course helped these particular students to focus on specific grammar rules and details on their own by using reference books.

[4] "The grammar assignments connected to the reading activities enabled me to focus on specific grammar rules and study the details on my own in some reference books which you recommended us to use. In this way, I improved myself in the rules that I didn't have any idea about. In this sense, they were useful."

[5] "Keeping a potfolio forced me to use some reference books to learn to use some grammar rules correctly while writing my essays."

The following opinions (\#6, \#7) indicate that the process led to raising the students' awareness about the errors made. These students report that they have begun to correct their errors at their present level, and they can do it more easily.

[6] "I like using grammar and vocabulary as a whole, and I see that I don't make simple mistakes anymore." 
[7] "I can correct my mistakes more easily and I can think long enough on my ideas before I put them on paper."

The following two opinions (\#8, \#9) reveal that the portfolio-keeping process helps the students express their ideas more clearly and easily.

[8] "Now, I can express my ideas more clearly. When I look at the first things I wrote at the beginning of the first term and the mistakes I made, I'm sure I'll laugh."

[9] "I feel that I can use grammar rules more correctly and I can express my ideas more clearly and easily."

Opinion \#10 shows us that the process gave this particular student an opportunity to consolidate what she learned previously in her high-school experiences.

[10] "My knowledge of grammar was quite good when I first started at the department, but now I see that I'm consolidating all the grammar rules I learned, and now I feel that I am better."

The following two opinions (\#11 and \#12) draw our attention to the fact that the process turns into a meaningful and enjoyable language learning act, and the students can observe the change in their level of development and fluency in writing.

[11] "To tell the truth, I found it too hard to write at first. Sometimes I couldn't find any ideas to write. There have been even times that I didn't feel like writing at all. As I saw that I could do it, it turned into a more enjoyable and meaningful activity. I never get bored now. Also, I see that I can write more fluently than I used to before I started at the department."

[12] "This year I got great pleasure out of writing, and I see that keeping a portfolio helps me develop my level of English."

The last opinion (\#13) related to language use reveals that the process forced this particular student to move back and forth in her essays to make changes or re-write sentences or parts. This means that this student is becoming more autonomous by developing a potential for the correction and evaluation of what she writes on her own.

[13] "After re-reading what I have written, I sometimes doubt that our teacher may find it too simple; and therefore, I feel the need to change or re-write many sentences or parts that I don't like in my essays."

\subsection{Reflections on Progress in Vocabulary Use}

Some opinions of the participants were on their progress in vocabulary use, so they were presented in groups reflecting various aspects of the process. Opinions \#1 and \#2 below indicate that portfolio keeping process has brought about a change for these particular students with respect to vocabulary learning.

[1] "So far in my life, I have never experienced such a task, except for looking up unknown words in dictionary and using them in sentences."

[2] "I try to use the new words in my sentences. This is one of the best ways not to forget these words. Every new paragraph I have written becomes more comprehensive and meaninful than the previous one thanks to the words I have learned."

When we have a look at the opinions \#3, \#4 and \#5, we can see that these students experienced a more conscious vocabulary learning process through portfolio-keeping, enabling them to use the key words again and again, so they can keep them in their long-term memory. This also seems to be resulting in accurate pronunciation of words. We can say that getting opportunities to express ideas through paraphrasing and discussion activities in the reading tasks promotes their progress in the speaking skill as well, using the vocabulary they have learned.

[3] "I believe that every writing activity contributed to our English and we got the opportunity to use the vocabulary we learned."

[4] "As we get opportunities to express our opinions in the reading course, we are also improving our speaking skill using the vocabulary we have learned."

[5] "Keeping a portfolio enabled me to use the vocabulary more consciously that we have learned in our classes. I use them again and again, so I can remember them easily. It also helped me improve my pronunciation. When I use them, I remember how they are pronounced as well."

The following three opinions $(\# 6, \# 7, \# 8)$ indicate that the process was perceived in a relaxed manner by the students with the support of vocabulary learned in the course and helped them to write more easily when compared to the simple words they used to prefer when they first started. The students reflect a message of satisfaction about using dictionary and doing dictionary assignments as part of their portfolio work, the progress made and the course itself. 
[6] "Now, I'm more relaxed because the vocabulary I have learned helps me write more easily. I can see that I don't use simple words anymore."

[7] "It is a good idea to work on vocabulary and make it a part of our portfolio. I got pleasure out of the dictionary work. This reflected into the content of my writing assignments."

[8] "I used to look up words in the dictionary more often in the past, and words wouldn't come to my mind easily. Now, I'm better. I'm pleased with the progress I have made."

On top of the development in vocabulary learning, opinions \#9, \#10 and \#11 tell us that these particular students are being more selective in word choice in their writing attempts.

[9] "Now I see that my vocabulary has developed a lot, and I can be more selective in word choice. For instance, when I write an essay or a paragraph, I don't use every word that comes to my mind, but I try to choose the most suitable ones. I feel that I'm being more sensitive about which words to select as I write."

[10] "As a student who got accustomed to the test technique, I have to say I found it difficult to write about the topics at the beginning of the course, but in time I realized that I took a long way in the use of vocabulary and grammar. The words I learned in the units helped me to select the right words which I needed to use."

[11] "I feel that I can use grammar and vocabulary more correctly and I can express my ideas more clearly and easily."

Opinions \#12 and \#13 show that the process forced the students to use dictionary to search for the right words as they wrote about various topics.

[12] "Keeping a portfolio forced me to use the dictionary for the right words more frequently."

[13] "Writing about various topics throughout the year enabled me to reflect my ideas and helped me to learn a lot of related vocabulary using my dictionary."

The first student who was interviewed says that the process forced her to be productive while writing her essays, and she seems to be satisfied with the progress she made in the course with respect to vocabulary learning and language use compared to her level prior to the course.

Illknur: "Keeping a portfolio has forced me to write. In time, I was aware of the fact that I had to put effort into it, and writing about every topic became a priority for me. It forced me to create a product each time I tried. I'm really satisfied with my progress. Especially my vocabulary has developed quite a lot. I tried to use the new words I learned each time I wrote about a topic. As I used the new words in each writing task in each unit, I could remember them whenever I needed. I can say that I can use English better now and express my thoughts more easily when I write. At the beginning of the school year I was afraid to put my ideas on paper."

The following student reports that he benefited from the portfolio process with respect to vocabulary the most, and he was not dependent on dictionary so much in the later stages of the course. He was able to reflect the vocabulary he learned into his writing assignments and could use them whenever he wanted to speak about a topic as well. This particular student sees his progress from simple sentences to more complex ones by using the words he learned as a significant progress.

Çağr1: "In this course, I got the opportunity to reflect the vocabulary I have learned into whatever I wrote. In time, I saw that I could remember some key vocabulary easily and I could use them when I speak about a topic as well. As the course progressed, I didn't need to use my dictionary very often. My vocabulary was limited when I started at the department, but I feel that I have learned quite a lot of useful vocabulary. I was always making simple sentences at first, but in time I started to make complex sentences. I could use few conjunctions in my writing, but now I can use them correctly and I can connect my sentences more easily."

Apart from the opinions which are directly related to development in language and vocabulary use, we also captured some opinions regarding the benefits of integration of language skills, self-assessment of personal progress and building self-confidence in language and vocabulary use.

\subsection{Reflections on the Benefits of Integration of Language Skills}

The following opinions draw our attention to the benefits of integrating language skills and the interaction taking place between them. According to the third opinion below, the progress made is regarded as a serious development, and this particular student can observe this change in the other classmates of hers as well.

[1] 'I'm learning new words every day and I'm trying to use them when I speak and write. And I see that my vocabulary is developing continuously. I also transfer what I learn in the speaking and listening course into the reading course and I can use them in writing as well. This helps me to express my ideas more clearly and 
easily."

[2] "Each time I attempt to write, I try to use the words that I have learned in the reading course. In this way, I can remember the key words whenever I attempt to speak in class. I personally don't find it so hard now to find words when I speak and I have more confidence to speak as well."

[3] "We developed our level not only in reading and writing, but also in speaking. I consider that this is a serious development. This is true not only for me but also for my classmates."

\subsection{Reflections on Self-Assessment of Personal Progress}

The following reflections from the interviews reveal that the students can assess their self-development not only in the writing skill but also in speaking skill, which indicates that the influence is multi-faceted. The reflections from the next three students indicate that the negative attitude towards writing in the target language changes to positive as a result of the portfolio-keeping process. The process was tiring, but it seems that the students benefited and got pleasure out of it as the course progressed, and they evaluate their individual progresses positively. They can compare their written products with the previous ones and observe the change in their development as they reach a higher level.

Cansu: "Keeping a portfolio is tiring, but it gives me pleasure. When I complete my writing assignments, it makes me proud. In my free-time, I always thought that I had something to write. I mean, it kept me very busy in my free-time. And I did all the assignments. When I look through my portfolio, I see that we have written on quite a lot of topics. I wouldn't have thought that I would be able to make so much progress in writing. Personally, I can say I benefited a lot."

Burhan: "I believe that every writing activity in my portfolio contributed to my level and I have improved myself in the writing skill from a low level to high-intermediate level, maybe advanced. When I look at the first things I wrote, I see that they were short and too simple. When I compare my first writing assignments with what I can write now, I can see that I have taken a long way. I can see that I have improved my writing skill in English. Now I believe that writing a lot really helps to improve my level, but I didn't use to think so at the beginning."

Hatice: "When I compare myself with the other friends in our group, I must admit that I come from a low level if the writing skill is concerned. But like a person going through a new process, I believe that I made a lot of progress in this course and I learned a lot. I feel I can write better now, and I'm sure I will continue to improve my level as I write."

\subsection{Reflections on Building Self-Confidence in Language and Vocabulary Use}

On top of raising students' self-awareness about personal development, portfolio process seems to help the students build their self-confidence in the use of English. The next student is not afraid of making mistakes when she writes and speaks in English and gives importance to pronunciation as well, which indicates an interaction of the two language skills with an impact on her self-confidence in the use of English.

Tuğba: “... I can observe the development in myself. Keeping everything we write in our portfolio helped me to be more confident whenever I write and speak. I now raise my hand without thinking to answer the questions. I'm not afraid to make mistakes when I'm using English orally. I also give more importance to pronunciation. When I'm writing about something, I also try to remember how we pronounce the words."

The following student also gives the message that he is sure of making further progress in his later studies.

Caner: "I have never written so much in English before. I think that I have taken a long way and I can say I trust myself more whenever I attempt to write and speak in English now, I mean, more than I felt at the beginning. In this course I was able to improve myself in the writing skill and I'm sure that I can do much better."

The following opinion indicates that the portfolio process influenced this particular student's study habits in spite of his complaint about the workload and helped him to build his self-confidence in writing and speaking, expressing himself intelligibly in English by using the words he learned in the course.

Cihangir: "The dose of the assignments was too much for me; therefore, this forced me a little at first and I had difficulty in organizing my study; however, as a result of this study, I succeeded in expressing my ideas more comfortably. I also learned to think faster and to express myself more intelligibly. This increased my confidence not only in writing, but also whenever I wanted to speak in English. For instance, I got the habit of speaking spontaneously. The new words I learned in our reading classes came to my mind quickly. As a whole, it was a good experience for me." 


\section{Discussion and Conclusion}

The students' opinions on their progress in language use indicate that supporting The Advanced Reading-Writing Skills Course with The Contextual Grammar Course enabled the students to focus on and consolidate the grammar rules they learned in their high-school experiences, using reference books while revising their assignments. The following thoughts and phrases that reflect the influence of portfolio-keeping process on students' progress in language covering grammar use specifically were identified in the opinions given:

1) ...was able to make longer sentences; 2) ... started to make more complex sentences; 3 ) ...enabled me to focus on specific grammar rules and study details on my own in reference books; 4) ...can use grammar rules more correctly while writing essays; 5) ... don't make simple mistakes anymore; 6) ...can correct my mistakes more easily and can think long enough on my ideas before putting them on paper; 7) ...can express my ideas more clearly and easily; 8) ...consolidating all the grammar rules I learned; 9) ...turned into more enjoyable and meaningful activity; 10) ...can write more fluently now; 11) ...got pleasure out of writing; 12) ...helps me develop my level of English; 13) ... feel the need to change or re-write many sentences or parts in my essays;

It seems that the portfolio-keeping process turned into a meaningful and enjoyable language learning act in time in spite of the fact that the students had a negative attitude and found it boring at the beginning of the course and later complained about the workload. The students reported that they were satisfied with their progress in language use with respect to the length and complexity of sentences they could write. As the course progressed, it seems that they got more pleasure out of the writing activities, and the process we followed helped the students reach a much higher level and fluency in writing and develop their self-confidence in using English. Speaking of complexity and fluency in language use, as Skehan (2001) suggests, "complexity can refer to the learners' preparedness to use a wide range of different structures" and that "complexity will depend on learners' willingness to take risks by experimenting linguistically" (in Ellis \& Barkhauizen, 2005). Whether we speak of the writing or speaking skill, as Skehan (2001) pointed out, "fluency is the production of language in real time without pausing or hesitation", and "it occurs when learners prioritize meaning over form in order to get a task done."

On the other hand, as the process gave the students enough time to think long enough on what they wrote each time, they had the opportunity to correct their mistakes while revising their written assignments on their own, which seems to have resulted in easier and clearer expression of ideas. In line with this, Lynch $(2008$, p. 2) suggests that, apart from peer-correction and teacher-correction, the most effective strategy for error correction is self-correction as learners can realize and learn from their mistakes. Johns (1995) also found that students find portfolio process useful for a number of reasons: They organize classwork and make goals transparent; they offer opportunities for comparison; they provide a measure for progress and change, and they assist students in correcting and revising their work. They also give students several chances to demonstrate what they can accomplish.

The students' opinions on their development in vocabulary indicate that they went through a conscious learning process as a result of the portfolio-keeping in this course, and it was quite distinct from their previous learning experiences. In other words, it brought about a change in the students' study skills. By revising the words they learnt, they increased the possibility of remembering the same words in other and similar contexts, and the process as a whole seems to have created a change in their pronunciation as well whenever they used English orally.

It seems that vocabulary development was perceived as a key element by the students in this course and they can observe the change in their written assignments - from simple vocabulary to more difficult ones. As they learned new words, they were reflected into their writing assignments. In this sense, the students seem to have found the vocabulary assignments useful as they used the key vocabulary in their writing tasks more easily, and in this way, they were able to observe their progress in vocabulary learning. As a result of a special focus on vocabulary study, the portfolio process seems to have created a success in word choice; in other words, the students became more selective and sensitive about which words to use.

Our students draw our attention to the benefits of integrating the language skills and the interaction taking place between them, saying that the progress they have made is as a serious development. More importantly, they can observe the degree of progress in their classmates as well.

Some opinions reveal that the portfolio process helps to raise the students' self-confidence in writing and speaking and they are not afraid of making mistakes when they are using English, which reveals an interaction between the two productive skills. In this sense, the process seems to assist the students in changing their negative attitude for the writing course to a positive one. The students can also compare their written products 
with the previous ones which they had written at the beginning of the course and observe the change in their progress in writing, which means that they can evaluate their progress on their own. Some student reflections from Johns's (1995) study support our findings:

"A portfolio can help me to become a better writer." "Since a portfolio is a collection of the works I did, I can look back to my earlier works." "By looking back, I can improve my weaknesses such as grammar and sentence structure." "I can also compare my earlier works with the later ones to see if I have improved or not."

Similarly, a study by Köse (2006) on the effects of portfolio implementation and assessment on critical reading and learner autonomy of ELT students in a Turkish context reveals that the students improved themselves in various language skills, such as language use, dictionary use, vocabulary strategies, reading and writing skills, which led them to become more and more efficient in their learning process. In this sense, in order to encourage students to make more effort in their portfolios and help them become aware of the benefits of portfolios, Kilıç (2009) suggests that schools might need to consider finding new and more effective ways of giving the initial information about portfolios to students. Kılıç also says that presenting students with the concept of portfolios as a part of the course might not help students much to internalize how portfolios can contribute to their learning. In addition to informing students about portfolio implementation, the aims of its use and the benefits of portfolios, showing some good examples of portfolios kept previously can be considered as the first step of involving students in the process.

Consequently, we can observe that the portfolio process within the integrated reading-writing course in our case helped our students change their study habits and express themselves intelligibly in the long run whenever they attempted to write and speak in the target language. The students report that they benefited from the vocabulary studies as well, moving from simple sentences to more complex ones and using the words correctly, which they consider as a significant progress. In this process, they also report that they benefited from the integration of language skills and built their self-confidence in the use of English not only when they write but also when they use English orally. Most important of all, they can evaluate the progress they have made comparing what they used to produce at the initial stage with what they can produce at later stages.

\section{References}

Arter, J. A., Spandel, V., \& Culham, R. (1995). Portfolios for assessment and instruction. ERIC Digest. Washington, DC: US Department of Education. (ED 388890). Retrieved from http://www.ericdigests.org

Brown, H. D. (2004). Language assessment: Principles and classroom practices. New York: Pearson Education.

Delett, J. S., Barnhardt, S., \& Kevorkian, J. A. (2001). A framework for portfolio assessment in the foreign language classroom. Foreign Language Annals, 34(6), 559-565. http://dx.doi.org./10.1111/j.1944-9720.2001.tb02103.x

Denzin, N. K., \& Lincoln, Y. S. (Eds.). (1994). Handbook of qualitative research. CA: Sage Publications.

Denzin, N. K., \& Lincoln, Y. S. (1998). Collecting and interpreting qualitative materials. Thousand Oaks, CA: Sage.

Dörnyei, Z. (2007). Research methods in Applied Linguistics. Oxford: Oxford University Press.

Ellis, R., \& Barkhuizen, G. (2005). Analyzing learner language. Oxford: Oxford University Press.

Fontana, A., \& Frey, J. H. (1994). Interview: The art of science. In N. K. Denzin, \& Y. S. Lincoln (Eds.), Handbook of qualitative research. CA: Sage Publications.

Gottlieb, M. (1995). Nurturing student learning through portfolios. TESOL Journal, 5(1), 12-14.

Hamp-Lyons, L., \& Condon, W. (2000). Assessing the portfolio: Principles for practice, theory, and research. Cresskill, NJ: Hampton Press.

Herman, J. L., Gearhart, M., \& Aschbacher, P. R. (1996). Portfolios for classroom assessment: Design and implementation issues. In R. Calfee, \& P. Perfume (Eds.), Writing portfolios in the classroom: Policy and practice, promise and peril. Mahwah, NJ: Lawrence Erlbaum Associates.

Johns, A. M. (1995). An excellent match: Literacy portfolios and ESP. English Teaching Forum, 33(4), 16-21.

Johnson, N. J., \& Rose, L. M. (1997). Portfolios: Clarifying, constructing, and enhancing. Lancaster: Technomic Publishing Company.

Kıliç, E. (2009). Portfolio implementation at Turkish university preparatory schools, and teachers' perceptions of portfolios and problems experienced with portfolio use (Unpublished M.A. thesis, Bilkent University, 
Faculty of Letters, Ankara).

Köse, N. (2006). Effects of portfolio implementation and assessment on critical reading and learner autonomy of ELT students (Unpublished doctoral dissertation, Çukurova University, The Institute of Social Sciences, Adana).

Lo, Y. (2010). Implementing reflective portfolios for promoting autonomous learning among EFL college students in Taiwan. Language Teaching Research, 14(1), 77-95. http://dx.doi.org/10.1177/1362168809346509

Lynch, L. M. (2008). English language error correction-A key language skills development tool. Retrieved July 13, 2010, from http://EzineArticles.com

Miles, M. B., \& Huberman, A. M. (1994). Qualitative data analysis. Thousand Oaks, CA: Sage.

Moya, S., \& O’Malley, J. M. (1994). A portfolio assessment model for ESL. The Journal of Educational Issues of Language Minority Students, 13, 13-36.

Mullin, J. A. (1998). Portfolios: Purposeful collections of student work. New Directions for Teaching and Learning, 74, 79-87. http://dx.doi.org./10.1002/tl.7408

Murphy, S., \& Camp, R. (1996). Moving towards systematic coherence: A discussion of conflicting perspectives in portfolio assessment. In R. Calfee, \& P. Perfume (Eds.), Writing portfolios in the classroom: Policy and practice, promise, and peril. Mahwah, NJ. Lawrence Erlbaum Associates.

Nunan, D., \& Lamb, C. (1996). The Self-directed teacher: Managing the learning process. Cambridge: Cambridge University Press.

O’Malley, J. M., \& Pierce, L. V. (1996). Authentic assessment for English language learners: Practical approaches for language teachers. Boston: Addison-Wesley.

Patton, M. Q. (2002). Qualitative research and evaluation methods (3rd ed.). Thousand Oaks, CA: Sage Publications.

Richards, J. C., \& Rodgers, T. (2001). Approaches and methods in language teaching (2nd ed.). Cambridge: Cambridge University Press.

Skehan, P. (2001). Tasks and language performance assessment. In M. Bygate, P. Skehan, \& M. Swain (Eds.), Researching pedagogic tasks: Second language learning, teaching and testing (pp. 167-185). London: Longman.

Strauss, A. L., \& Corbin, J. (1990). Basics of qualitative research: Grounded theory procedures and techniques. Newbury Park, CA: Sage.

Tailor, G. R. (2005). Integrating quantitative and qualitative methods in research (2nd ed.). Maryland: University Press of America.

Trumbull, M. (2005). Qualitative research methods. In G. R. Tailor (Ed.), Integrating quantitative and qualitative methods in research (2nd ed.). Maryland: University Press of America.

Weigle, S. C. (2002). Assessing writing. Cambridge University Press.

Yıldırım, A., \& Şimşek, H. (2008). Sosyal Bilimlerde Nitel Araştırma Yöntemleri (7th ed.). Ankara: Seçkin Yayıncilik.

\section{Copyrights}

Copyright for this article is retained by the author(s), with first publication rights granted to the journal.

This is an open-access article distributed under the terms and conditions of the Creative Commons Attribution license (http://creativecommons.org/licenses/by/3.0/). 